\title{
UPAYA MENINGKATKAN KEPUTUSAN PENGGUNAAN MEETING PACKAGE DI HOTEL BUMI ASIH JAYA BANDUNG MELALUI DEMAND BASED PRICING METHODS
}

(Survei pada Tamu Wisatawan Bisnis Pengambil Keputusan Penggunaan Meeting Package Di Hotel Bumi Asih Jaya Bandung)

\author{
Mohamad Fauzan \\ Heri Puspito Diyah Setiyorini \\ Manajemen Pemasaran Pariwisata FPIPS UPI
}

\begin{abstract}
Tourism is an industry thath as the potential to become an instrument of increasing foreign exchange earnings. The sector is evolving as it has become a necessary to travel along with the development of tourism social-culture undergoing changes. One of the tourism industry that is always growing increasingly is hospitality industry. Especially in hotel industry. Competitionin hotel industry in Indonesia, especially Bandungkeep growing fast. The key to success in the hotel management not only in terms of services but also from elements of the products and pricing. Those become an valuable asset it self and important in general. Hotel Bumi Asih Jaya Bandung is one of three stars hotel which always strive to provide variety of products through pricing approach. Demand-based pricing method pricing methods that focus on the customer's perspectiveis consistent with the pricing on the customer's perception of value to affect the decision of using meeting package. As the above background, the research conducted on the effects of demand-based pricing methods toeard to purchase decisionof meeting package. The purpose of this study was to determine how the demand-based pricing methods and purchase decision of meeting package at Hotel Bumi Asih Jaya Bandung, and to know how bigthe influence of demand-based pricing methods toward to purchase decision of meeting package. This study is descriptive and verifikatif, whilehis method is a descriptive survey and survey eksplanatory. Samples takenin this study population as many as 48 people. Sampling techniqueis carried out the census. Data processing is done using parametric statistical test which uses the formula path analysis via SPSS11.5 for Windows. The results showed that the dimensions of demand-based pricing methods that get the highest ratings on the dimensions of the buyer based pricing. While making use of sub-variables that get the highest ratings at the time of use. Demand based pricing methods that consist of buyers based pricing, psychologicalpricing, and negotiation has a positive effect amounting against the decisions of the use of meeting package at Hotel Bumi Asih Jaya Bandung, which means the better the demand-based pricing methods that have the higher the usage decision meetings package is formed.
\end{abstract}

\section{PENDAHULUAN}

\subsection{Latar Belakang Penelitian}

Sektor pariwisata adalah sebuah sektor yang sangat dinamis dan menempati urutan ketiga dalam meningkatkan devisa nonmigas setelah kayu dan tekstil, tetapi saat ini krisis ekonomi global dalam bulan-bulan terakhir ini diyakini akan berdampak terhadap sektor pariwisata khususnya kunjungan wisatawan dari negara-negara yang terkena krisis. Organisasi Pariwisata Dunia PBB United Nation World Tourist Organization (UNWTO) mengungkapkan, kunjungan wisatawan mancanegara selama empat bulan pertama 2009 menunjukkan penurunan sekitar $8 \%$ dibanding periode yang sama di tahun 2008. Namun pada tahun 2010 ini United Nation World Tourist
Organisation merespon tantangan dampak krisis global itu dengan memfokuskan penanganan dengan memperhatikan tiga pilar yang saling berkaitan yaitu kebijakan responsif, stimulus, dan pengembangan berwawasan lingkungan (green economy).

Sektor pariwisata dunia secara umum sedang mengalami penurunan, tetapi pariwisata Indonesia tetap tumbuh positif pada tahun 2009 dan pada 2010, Indonesia menargetkan mampu mendapatkan tujuh juta wisatawan mancanegara dengan perolehan devisa US $\$ 6,75$ miliar dan menggerakkan wisatawan nusantara atau wisnus sebesar 230 juta perjalanan dengan pengeluaran Rp138 triliun.

Pariwisata Indonesia menghadapi tiga tantangan serius sepanjang tahun 2009 yakni kasus flu babi, krisis global, dan terorisme 
melalui aksi pemboman. Meskipun begitu, sektor pariwisata Indonesia pada akhirnya mampu bertahan bahkan tumbuh positif hingga akhir tahun, dengan adanya program Visit Indonesia Year tahun 2009 yaitu wisata MICE (Meeting Incentive Convention and Exhibition) dan wisata bahari. Indonesia tidak perlu takut lagi, karena dua bidang wisata tersebut merupakan sektor wisata yang tidak terpengaruh dengan kondisi keamanan suatu negara. (Kemenbudpar, 2010)

Beberapa daerah di Indonesia melakukan berbagai promosi untuk mendatangkan wisatawan agar berkunjung ke daerah tersebut dengan membuat slogan pariwisata pada masing-masing daerah seperti Jawa Barat dengan slogan "Visit West Java”. Salah satu daerah tujuan wisata yang menjadi strategi pengembangan pariwisata nusantara adalah Jawa Barat.

Pengembangan wisata Jawa Barat didukung oleh keberagaman budaya dan pesona alam yang memikat dari setiap kota dan kabupaten. Jawa Barat memiliki 360 objek wisata, diantaranya 214 objek wisata alam, 73 wisata budaya dan 73 objek wisata khusus. Sektor pariwisata Jawa Barat akan terus berkembang dengan mendorong lewat pendanaan pada kabupaten atau kota untuk memperbaiki fasilitas dan infrastuktur tempat wisata (Wakil Gubernur Jawa Barat: 2010).

Bandung merupakan Ibu Kota Jawa Barat yang memang menjadi salah satu pilihan bagi wisatawan yang ingin melakukan kegiatan berwisata. Kota yang di kenal sebagai Paris Van Java ini adalah icon dari Provinsi Jawa Barat karena memiliki sejarah yang baik dimata dunia, Kota Bandung menjadi tujuan destinasi utama masyarakat mancanegara dan nusantara yang berkunjung. Perkembangan pariwisata Kota Bandung didukung oleh ketersediaan dan variasi produk wisata alam, sejarah, budaya, belanja dan wisata kuliner dengan prasarana dan sarana pariwisata yang memadai.

Kota Bandung hingga saat ini mempunyai 52 hotel berbintang, 166 hotel melati, 121 restoran, serta berbagai pusat perbelanjaan seperti factory outlet yang terus berkembang, dengan pendapatan rata-rata Rp.78 miliar/tahun (Wali Kota Bandung: 2010). Seiring dengan cepatnya tingkat pertumbuhan sarana akomodasi di Kota Bandung, sektor pariwisata menjadi suatu peluang bisnis yang sangat menjanjikan di Kota Bandung ini.

Keberadaan akomodasi sudah menjadi hal yang sangat penting sekali di industri pariwisata, hal ini sudah ditegaskan dalam Undang-Undang Nomor 10 tentang kepariwisataan pada BAB VI pasal 14 mengenai usaha pariwisata butir $\mathrm{F}$ yaitu penyediaan akomodasi, karena dengan adanya akomodasi para wisatawan dapat menghabiskan waktunya dengan menginap di hotel yang wisatawan inginkan.

Menurut

Undang-Undang

kepariwisataan BAB I pasal 1 mengenai ketentuan umum butir 1, wisata adalah kegiatan perjalanan yang dilakukan oleh seseorang atau sekelompok orang dengan mengunjungi tempat tertentu untuk tujuan rekreasi, pengembangan pribadi, atau mempelajari keunikan daya tarik wisata yang dikunjungi dalam jangka waktu sementara, dan pada butir 2, wisatawan adalah orang yang melakukan wisata. Namun minat para wisatawan saat ini selain berwisata, mereka juga melakukan kegiatanMeeting, Incentive, Convention dan Exhibition (MICE), hal ini telah menjadi trend baru di dunia pariwisata dan menjadi primadona dikalangan para pembisnis sekaligus wisatawan.

Beberapa hotel di Kota Bandung yang menyediakan fasilitas untuk kegiatan para wisatawan yang datang berkunjung untuk melakukan kegiatan MICE dan leisure di Bandung, terutama di Bandung Selatan, seperti Hotel Lingga, Hotel Baltika, Hotel Endah Parahyangan, dan Hotel Alam Permai. Sekian banyak hotel berbintang memilih menjadi hotel bisnis hal ini dikarenakan potensi dari wisatawan yang melakukan kegiatan MICE sangat tinggi di Bandung dan strategi itu juga dilakukan oleh Hotel Bumi Asih Jaya Bandung.

Hotel Bumi Asih Jaya Bandung merupakan hotel chain berbintang 3 dari PT. Puri Insan Asih Jakarta Managementyang berlokasi di Jalan Soekarno Hatta. Sebagai hotel bisnis, Hotel Bumi Asih Jaya Bandung selalu berusaha menarik sebanyak mungkin tamu yang berasal dari segmentasi pasar bisnis, namun segmentasi pasar individual pun tidak dilupakan begitu saja.

Tingginya kegiatan MICE yang ada di Hotel Bumi Asih Jaya Bandung, sedikit banyak mempengaruhi tingkat okupansi hotel, namun jika dibandingkan dengan para pesaingnya tingkat okupansi Hotel Bumi Asih Jaya Bandung masih berada di bawah para pesaingnya. Berikut ini adalah tingkat okupansi Hotel Bumi Asih Jaya Bandung selama 2009: 


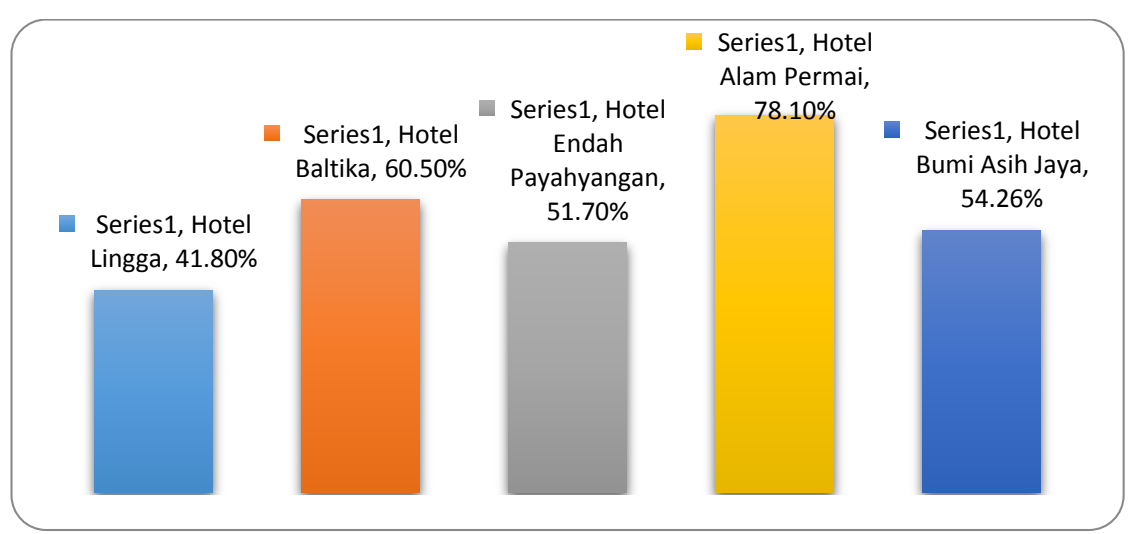

Sumber: Sales \& Marketing Department Hotel Bumi Asih Jaya Bandung, 2010

\section{GAMBAR 1}

\section{TINGKAT OKUPANSI HOTEL BUMI ASIH JAYA BANDUNG BESERTA PESAING-} PESAINGNYA SELAMA TAHUN 2009

Berdasarkan Gambar 1, dapat diketahui tingkat okupansi Hotel Bumi Asih Jaya Bandung masih kalah dengan para pesaing di dekatnya dan belum menjadi top leader antara pesaingnya yaitu sebesar 54,26\%, 78,10 (Hotel Alam Permai), 51,70\% (Hotel Endah Parahyangan), 60,50\% (Hotel Baltika), dan 41,80 (Hotel Lingga). Rendahnya tingkat okupansi Hotel Bumi Asih Jaya Bandung menjadi salah satu tugas bagi pihak manajemen hotel dalam meningkatkan jumlah tamunya untuk dapat bersaing dengan hotel lainnya.
Salah satu penyebab rendahnya tingkat okupansi hotel adalah lokasi Hotel Bumi Asih Jaya yang tidak berada di pusat kota, jauh dari keramaian, tempat-tempat hiburan, factory outlet dan lain-lainnya yang bersifat menghibur, meskipun terdapat di Jalan Soekarno Hatta yang merupakan salah satu jalan besar di Kota Bandung. Tingkat okupansi yang rendah berpengaruh juga terhadap tingkat penggunaan meeting package di Hotel Bumi Asih Jaya Bandung. Berikut ini data tingkat penggunaan meeting package Hotel Bumi Asih Jaya Bandung beserta pesaingnya:

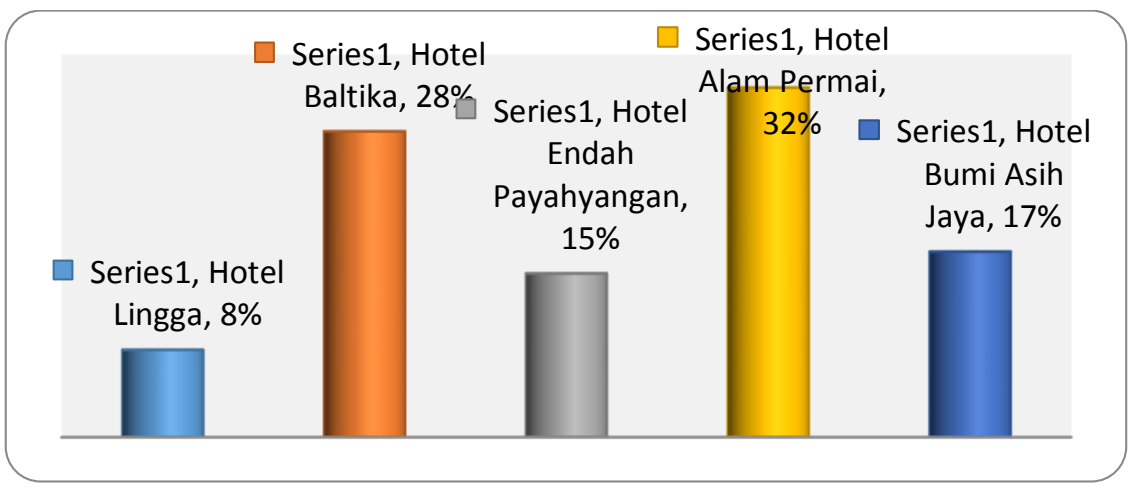

Sumber: Sales \& Marketing DepartmentHotel Bumi Asih Jaya Bandung, 2010

GAMBAR 2

TINGKAT PENGGUNAAN MEETING PACKAGE HOTEL BUMI ASIH JAYA BANDUNG BESERTA PESAING-PESAINGNYA SELAMA TAHUN 2009

Berdasarkan Gambar 2, dapat diketahui rata-rata tingkat penggunaan meeting package di Hotel Bumi Asih Jaya Bandung sebesar $17 \%$, yang menempati posisi ketiga dari para pesaingnya. Tingkat penggunaan meeting package Hotel Bumi Asih Jaya Bandung masih dibawah rata-rata, dikarenakan tingkat persaingan yang tinggi dan lokasi hotel yang saling berdekatan dengan hotel pesaing. Hal ini menjadi suatu masalah yang berada di Hotel Bumi Asih Jaya Bandung sebagai predikatnya sebagai hotel bisnis. Meskipun dapat dilihat dari fasilitas yang tidak berbeda jauh tetapi faktor 
perbedaan harga yang membuat tamu melihat hotel lain.

Pendapatan Hotel Bumi Asih Jaya Bandung yang paling besar yaitu dari hasil penjualan meeting package. Oleh sebab itu, perhatian manajemen lebih banyak ditumpahkan pada penjualan meeting package dengan meningkatkan keputusan penggunaan sesuai segmen pasarnya yaitu tamu bisnis. Meeting package inilah yang menjadi fokus utama Hotel Bumi Asih Jaya Bandung, ditambah dengan fenomena yang ada pada saat ini dimana kebutuhan akan MICE bisa dikatakan sangat tinggi, kesadaran adanya kebutuhan itu menjadi salah satu motivasi bagi Hotel Bumi Asih Jaya Bandung untuk tetap exist dalam dunia perhotelan walaupun tingkat okupansi dan tingkat penggunaan meeting package di Hotel Bumi Asih Jaya Bandung masih kalah dibanding para pesaingnya.

Pasar bisnis merupakan pasar yang sangat prospektif dan dapat memberi dampak langsung terhadap pendapatan hotel dan juga tingkat okupansi hotel. Hal ini dikarenakan kedatangan tamu bisnis ini cenderung berkelompok. Hotel Bumi Asih Jaya Bandung harus tetap fokus terhadap banyaknya tamu yang membeli meeting package, khususnya yang berasal dari pasar corporate dan government. Berikut ini adalah data mengenai segmen pasar corporate dan pasar government di Hotel Bumi Asih Jaya Bandung:

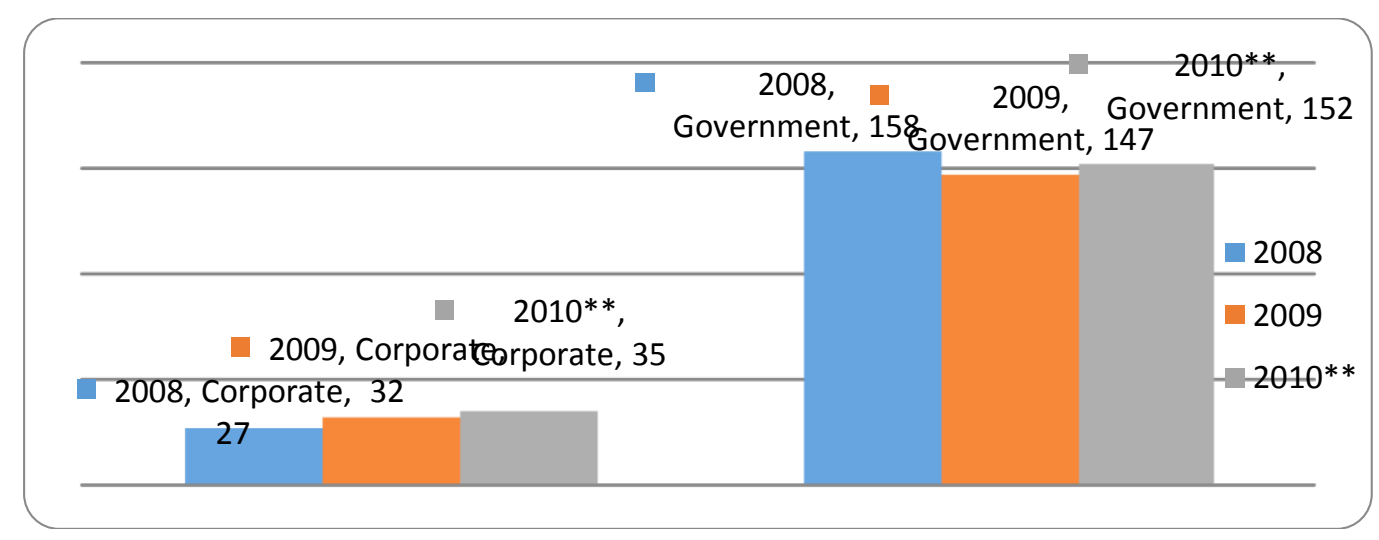

Sumber: Sales \& Marketing DepartmentHotel Bumi Asih Jaya Bandung, 2010

\section{GAMBAR 3 \\ JUMLAH SEGMEN PASAR CORPORATE DAN GOVERNMENT DIHOTEL BUMI ASIH JAYA BANDUNG}

Berdasarkan Gambar 3 dapat diketahui segmen corporatedari Hotel Bumi Asih Jaya Bandung mengalami kenaikan di tahun 2010 sebesar 3\%, sedangkan dari segmen government mengalami kenaikan di tahun 2010 sebesar 5\%. Hal ini tidak terlepas dari kinerja marketing dalam memasarkan produk meeting package yang dimilikinya, sehingga rata-rata tingkat hunian kamar tertinggi didominasi oleh tamu bisnis, terutama jika perusahaan-perusahaan tersebut mengadakan meeting, event, pameran, gathering atau dengan tujuan bisnis lainnya.

Hotel Bumi Asih Jaya Bandung terus melakukan berbagai macam strategi untuk mengusahakan agar meeting room yang dimiliki dapat digunakan secara maksimal pada high season maupun low season. Berikut ini, beberapa strategi yang dilakukan Hotel Bumi Asih Jaya Bandung untuk menarik para tamu hotel khususnya tamu yang penggunaan meeting package yang menjadi targetnya: 


\section{TABEL 1 \\ STRATEGI-STRATEGI PEMASARAN YANG DILAKUKAN OLEH HOTEL BUMI ASIH JAYA BANDUNG DALAM MENARIK \\ TAMU BISNIS}

\begin{tabular}{ll}
\hline Product & $\begin{array}{l}\text { Mengeluarkan produk baru yang bernama ResidentialMeeting Package yaitu sebuah } \\
\text { paket meeting yang mempunyai fasilitas kamar executive, breakfast, dinner, lunch, } \\
\text { and } 2 \text { times caffee break dengan harga yang terjangkau. }\end{array}$ \\
\hline Price & $\begin{array}{l}\text { Menetapkan penetration pricing yaitu menetapkan harga produk yang serendah- } \\
\text { rendahnya untuk mencapai volume penjualan setinggi-tingginya. }\end{array}$ \\
Place & $\begin{array}{l}\text { Meluncurkan tujuh tempat ruang meeting dengan berbagai fungsinya guna } \\
\text { memenuhi permintaan para tamu bisnis, yang dapat menampung } 10 \text { sampai } 1.000 \\
\text { orang dengan harga yang terjangkau. }\end{array}$ \\
Promotion & $\begin{array}{l}\text { Direct Action Advertising yaitu mengadakan iklan produk yang didesain untuk } \\
\text { meningkatkan permintaan dari tamu bisnis dengan program promo discount tiap } \\
\text { bulannya. }\end{array}$ \\
\hline
\end{tabular}

Sumber: Modifikasi Sales \& Marketing DepartmentHotel Bumi Asih Jaya Bandung 2010

Berdasarkan Tabel 1 dapat diketahui bahwa marketing mix adalah strategi yang dijalankan oleh Hotel Bumi Asih Jaya Bandung, dimana marketing mix ini adalah alat bagi pemasar dalam memasarkan produk yang dimiliki hotel. Tidak hanya produk yang dijual, namun faktor pendukung khususnya pricing menjadi fokus utama dalam menjalankan strategi untuk menghadapi persaingan harga yang sangat kompetitif dalam meraih pangsa pasar dari industri hospitality khususnya perhotelan. Hotel Bumi Asih Jaya Bandung melakukan pricing strategy dengan penuh pertimbangan, karena strategi tersebut akan mempengaruhi pendapatan total dan biaya hotel, dengan tidak mengesampingkan untuk memantau harga para pesaing. Berikut harga meeting package Hotel Bumi Asih Jaya Bandung tahun 2009 beserta pesaingnya:

TABEL 2

HARGA MEETING PACKAGE HOTEL BUMI ASIH JAYA BANDUNG BESERTA PESAING-PESAINGNYA TAHUN 2009

\begin{tabular}{|c|c|c|c|c|c|c|}
\hline & \multicolumn{2}{|c|}{ Half Day } & \multicolumn{2}{|c|}{ Full Day } & \multicolumn{2}{|c|}{ Full Board } \\
\hline & 2008 & 2009 & 2008 & 2009 & 2008 & 2009 \\
\hline Hotel Lingga & Rp.110,000 & Rp.100.000 & Rp. 150,000 & Rp. 140.000 & Rp.345,000 & Rp.345.000 \\
\hline Hotel Baltika & Rp. 120,000 & Rp.110.000 & Rp. 150,000 & Rp. 140,000 & Rp.340,000 & Rp. 325,000 \\
\hline $\begin{array}{l}\text { Hotel Endah } \\
\text { Payahyangan }\end{array}$ & Rp.110,000 & Rp. 100,000 & Rp. 140,000 & Rp. 120,000 & Rp.345,000 & Rp.350.000 \\
\hline Hotel Alam Permai & Rp. 120,000 & Rp.110.000 & Rp. 140,000 & Rp. 130,000 & Rp.370,000 & Rp.360,000 \\
\hline Hotel Bumi Asih Jaya & Rp.120,000 & Rp.100,000 & Rp.145.000 & Rp.125,000 & Rp.360.000 & Rp.350,000 \\
\hline
\end{tabular}

Sumber: Sales \& Marketing Department Hotel Bumi Asih Jaya Bandung, 2010

Berdasarkan Tabel 2 dapat dilihat persaingan harga meeting package yang tinggi dengan fasilitas yang tidak berbeda jauh bahkan sama antara Hotel Bumi Asih Jaya Bandung dengan pesaing-pesaingnya, menimbulkan masalah antara harga dengan keputusan tamu untuk penggunaan meeting package yang ada di Hotel Bumi Asih Jaya Bandung. Berdasarkan perbandingan harga pada tahun 2009 dengan pesaing Hotel Bumi Asih Jaya Bandung yang tingkat penggunaan meeting package paling tinggi yaitu Hotel Alam Permai. Perbedaan harga halfday package sebesar Rp.10.000, full day package sebesar Rp.5.000, dan full board sebesar
Rp.10.000. Perbedaan harga yang begitu tipis ini dapat berpengaruh terhadap keputusan tamu untuk penggunaan, maka hotel Bumi Asih Jaya Bandung menurunkan harganya ditahun 2009 untuk meningkatkan permintaan pengguna baru dan memperbesar tingkat penggunaan dengan memperluas pasar yang dilayani dan mempertahankan atau meningkatkan permintaan tamu yang sudah ada.

Menurut Ali Hasan (2009:302) mengungkapkan bahwa kondisi persaingan sangat mempengaruhi penentuan harga. Berdasarkan pernyataan tersebut, tingkat persaingan yang tinggi menuntut Hotel Bumi 
Asih Jaya Bandung harus selalu berupaya semaksimal mungkin untuk menciptakan keputusan penggunaan para tamunyadan mempertahankan yang sudah ada dengan menetapkan harga yang tepat untuk produknya.

Adanya sensitifitas harga yang dirasakan tamu yang ingin mendapatkan suatu produk yang bagus dengan harga yang terjangkau, menimbulkan konsumen beralih kepada hotel lain yang menawarkan produk yang sama dengan harga yang lebih murah. Oleh karena itu pricing strategy yang dilakukan oleh Hotel Bumi Asih Jaya Bandung belum tentu dapat dijalanakan dengan mudah dan sangat sulit dilakukan dalam persaingan yang tinggi. Menurut Fandy Tjiptono (2009:155) mengatakan semakin banyak jumlah penawaran alternatif sejenis, semakin besar pula tekanan bagi para manajer pemasaran untuk menetapkan harga pada tingkat yang sama atau di bawah harga pesaing.

Pernyataan di atas membuat Hotel Bumi Asih Jaya Bandung harus lebih bekerja keras lagi untuk meningkatkan tingkat penggunaan meeting package dengan menciptakan keputusan penggunaan meeting package pada tamu bisnis yang menjadi target pasar Hotel Bumi Asih Jaya Bandung. Selanjutnya Simon Hudson (2008:189) mengatakan bahwa pricing strategy tersebut memiliki tiga aspek yaitu cost based methods, demand based methods, dan competition oriented, dalam situasi saat ini Hotel Bumi Asih Jaya Bandung menggunakan pricing strategy yang lebih menitikberatkan pada demand based methods guna mempertahankan posisinya di lingkungan persaingan yang semakin tinggi.

Menurut Simon Hudson (2008:191) berpendapat "Techniques in the demand based category share the feature of giving major consideration to the consumer." Berbagai Strategi demand based pricing methods yang ada seperti buyer based pricing, psychological pricing, dannegotiating menjadi fokus utama Hotel Bumi Asih Jaya Bandung untuk meningkatkan dan menciptakan keputusan penggunaan meeting package yang ditawarkan pihak hotel.

Strategi buyer based methods yang dilakukan Hotel Bumi Asih Jaya Bandung adalah harga yang telah dipublish oleh pihak hotel kepada tamu bisninya seperti harga meeting package halfday dengan harga Rp.100.000 include satu kali coffee break dan satu kali lunch, fullday dengan harga Rp.125.000 include dua kali coffee break dan satu kali lunch, dan fullboard dengan harga Rp.350.000 include dua kali coffee break, satu kali breakfast, satu kali lunch, dan satu kali dinner. Harga yang telah dipublish oleh pihak hotel ini sudah termasuk fasilitas pendukung seperti infocus dengan screen, white board, flip chart, memo pad dengan pencil, sound system, dan mineral water.

Strategi psychological pricing yang dilakukan Hotel Bumi Asih Jaya Bandung adalah memberikan pelayanan dan fasilitas yang berkualitas dan memberikan discountdiscount khusus meeting package kepada tamu corporate dan government. Pemberian harga meeting package yang telah dipublish dengan harga yang didiscount sebesar $10 \%$ kepada tamu corporate dikarenakan tamu ini lebih memperhatikan setiap pengeluaran yang dilakukan perusahaannya, sedangkan pemberian harga meeting package yang telah dipublish dengan harga yang didiscount sebesar $20 \%$ kepada tamu goverment dikarenakan banyaknya kegiatan yang dilakukan oleh perusahaan setiap tahunnya, banyaknya frekuensi penggunaan akan memudahkan pihak hotel menetapkan harganya lebih fleksibel. Penetapan harga ini akan menarik tamu untuk mencobanya, ataupun untuk tamu yang sudah loyal menambah frekuensinya dalam penggunaan meeting package yang ditawarkan tanpa mengabaikan kualitas produk dan pelayanan.

Strategi negotiating yang dilakukan Hotel Bumi Asih Jaya Bandung menjadi bagian dari demand based pricing methods dikarenakan presentase dari discount disepakati oleh kedua belah pihak melalui marketing departement, hal ini dijadikan strategi bagi Hotel Bumi Asih Jaya Bandung untuk menciptakan keputusan penggunaan meeting package yang ditawarkan melalui penetapan harga. Kriteria tamu-tamu yang datang ke Hotel Bumi Asih Jaya Bandung merupakan tamu group yang sudah menjadi pelanggan dimana masing-masing sub variabel dari demand based pricing methods mewakili semua tamu group baik itu tamu corporate maupun tamu government. Penetapan harga ini bertujuan untuk mendapatkan kesepakatan antara kedua belah pihak agara dapat terciptanya win-win solution. Kebebasan untuk memilih sesuai dengan permintaan dan penawaran tamu akan memberikan kenyamanan dalam menggunakan meeting package yang ditawarkan oleh hotel, karena ada beberapa 
faktor yang menyebabkan Hotel Bumi Asih Jaya Bandung harus selalu meninjau kembali terhadap perubahan lingkungan pemasaran ataupun pergesaran permintaan yang dapat memberikan penilaian kembali terhadap strategi penetapan harga yang telah dilakukan.

Demand based pricing methods yang dijalankan oleh Hotel Bumi Asih Jaya Bandung bertujuan untuk mendatangkan pemasukan bagi hotel dan berguna untuk mempengaruhi keputusan penggunaan meeting package. Selain itu harga juga berperan sebagai Strategi yang paling visible bagi para konsumen. Oleh karena itu masalah yang timbul disini adalah sampai sejauh mana deman based pricing methods dapat memberikan pengaruh terhadap keputusan penggunaan meeting package di Hotel Bumi Asih Jaya Bandung. Berdasarkan latar belakang di atas maka perlu diadakan suatu penelitian tentang: "UPAYA MENINGKATKAN KEPUTUSAN PENGGUNAANMEETING PACKAGE DI HOTEL BUMI ASIH JAYA BANDUNG MELALUI DEMAND BASED PRICING METHODS" (Survei pada tamu wisatawan bisnis pengambil keputusan penggunaan meeting package di Hotel Bumi Asih Jaya Bandung).

\subsection{Rumusan Masalah}

Berdasarkan latar belakang di atas, maka dapat dirumuskan masalah penelitian sebagai berikut:

1. Bagaimana demand based pricing methods yang terdiri dari buyer based pricing, psychological pricing, dan negotiating di Hotel Bumi Asih Jaya Bandung.

2. Bagaimana keputusan penggunaan meeting package di Hotel Bumi Asih Jaya Bandung.

3. Seberapa besar pengaruh demand based pricing methods yang terdiri dari buyer based pricing, psychological pricing, dan negotiating terhadap keputusan penggunaan meeting package di Hotel Bumi Asih Jaya Bandung.

\subsection{Tujuan Penelitian}

Berdasarkan rumusan masalah di atas, maka penelitian ini bertujuan untuk memperoleh hasil temuan mengenai:

1. Demand based pricing methods yang terdiri dari buyer based pricing, psychological pricing, dan negotiating pada Hotel Bumi Asih Jaya Bandung.
2. Keputusan penggunaan meeting package di Hotel Bumi Asih Jaya Bandung.

3. Demand based pricing methods yang terdiri dari buyer based pricing, psychological pricing, dan negotiating terhadap keputusan penggunaan meeting package di Hotel Bumi Asih Jaya Bandung.

\subsection{Kegunaan Penelitian}

1. Secara Teoritis

Dapat memberikan tambahan pengetahuan dan memperluas mengenai ilmu-ilmu marketing khususnya demand based pricing methods yang terdiri buyer based pricing, psychological pricing, dan negotiating yang berpengaruh terhadap keputusan penggunaan pada tamu bisnis.

2. Secara Praktis

Dapat memberikan masukan kepada pihak Hotel Bumi Asih Jaya Bandung dalam hal ilmu marketing khususnya demand based pricing methods agar dapat menetapkan harga yang tepat untuk meningkatkan keputusan penggunaan meeting package Hotel Bumi Asih Jaya Bandung.

\section{KAJIAN PUSTAKA}

\subsection{Kerangka Pemikiran}

Perusahaan jasa merupakan sektor ekonomi yang sangat besar dan tumbuh sangat pesat. Pertumbuhan tersebut selain diakibatkan oleh pertumbuhan jenis jasa yang sudah ada sebelumnya, juga disebabkan oleh munculnya jenis jasa baru, sebagai akibat dari tuntutan dan perkembangan teknologi. Sudutpandang dari konteks globalisasi, pesatnya pertumbuhan perusahaan jasa antar negara ditandai dengan meningkatnya intensitas pemasaran lintas negara serta terjadinya aliansi berbagai penyedia jasa di dunia.

Pada dasarnya manusia itu memiliki kebutuhan yang harus dipenuhi, oleh sebab itu setiap perusahaan yang bergerak di bidang produk dan jasa harus memiliki berbagai strategi untuk mendapatkan apa yang diharapkan sebuah perusahaan. Menurut Kotler dan Keller (2009:7), pemasaran adalah suatu proses sosial dan manajerial dimana individu-individu dan kelompok-kelompok mendapatkan apa yang mereka butuhkan dan inginkan dengan melalui penciptaan, penawaran, dan pertukaran produk-produk yang bernilai.

Berbagai elemen yang dapat menunjang tumbuhnya perusahaan produk 
dan jasa yang sedang dikelola, dengan tidak terlepas dari strategi yang dijalankan oleh perusahaan tersebut, dalam teori marketing mix yang diungkapkan oleh Lovelock (2011:44) terdapat tujuh bauran pemasaran yang sering digunakan dalam pelayanan yang terdiri dari product, price, place, promotion, people, process and physical evidence, tetapi menurut Kotler dan Keller (2009:63), mengatakan harga merupakan satu-satunya bauran pemasaran yang menghasilkan pendapatan, sedangkan unsur lainnya menimbulkan biaya. Harga juga merupakan salah satu unsur bauran pemasaran yang paling fleksibel dan dapat diubah dengan cepat.

Keputusan dalam penetapan harga tidaklah mudah dilakukan, Fandy Tjiptono (2009:137) mengatakan bahwa harga yang terlalu mahal bisa meningkatkan laba jangka pendek, tetapi akan sulit dijangkau konsumen dan sukar bersaing dengan kompetitor. Sedangkan menurut Ali Hasan (2009:302) mengatakan bahwa kondisi persaingan sangat mempengaruhi penentuan harga. Oleh karena itu, marketer perlu mengetahui reaksi persaingan yang terjadi dipasar serta sumbersumber yang menyebabkan persaingan itu terjadi, umumnya persaingan bersumber dari produk sejenis yang dihasilkan oleh perusahaan lain (produk subtitusi). Situasi persaingan yang semakin tinggi saat ini membuat para pelaku pembisnis melakukan berbagai strategi harga termasuk strategi harga dalam produk yang sudah mapan. Meskipun produk itu sudah mapan di pasar luar, perusahaan harus selalu meninjau kembali strategi penetapan harga yang disebabkan perubahan selera konsumen atau perubahan lingkungan persaingan.

Simon Hudson (2008:192) Penetapan harga yang berfokus pada demand based methods, perusahaan memiliki empat alternatif strategi yang terdiri dari buyer based pricing, psychological pricing, negotiation dan price lining.

Buyer based pricing, merupakan strategi yang menetapkan harga sesuai dengan permintaan dan penawaran konsumen terhadap suatu produk. Strategi ini efektif dalam memberikan kenyaman dan nilai lebih kepada konsumen terhadap kualitas sebuah produk yang ditawarkan perusahaan. Perspektif konsumen terhadap harga yang diinginkan mempermudah perusahaan untuk melakukan segmentasi pasar yang dilayani misalnya, untuk melayani para pelanggan yang tidak terlalu sensitif terhadap harga. Jika strategi ini berhasil diterapkan, maka perusahaan akan menikmati marjin penjualan yang lebih besar, pasar yang tersegmentasi dan dapat meningkatkan hubungan baik antara perusahaan dengan konsumennya.

Psychological pricing, dilakukan untuk mempengaruhi persepsi konsumen dalam hubungan harga dengan nilai. Strategi ini bertujuan untuk menarik konsumen untuk membeli produk yang telah ditawarkan oleh perusahaan dan mengurangi sensitifitas konsumen terhadap harga tanpa mengurangi pandangan konsumen terhadap kualitas sebuah produk. Adanya perubahan lingkungan konsumen dan pesaing membuat konsumen mencari berbagai alternatif agar biaya yang dikeluarkannya lebih efisien dengan apa yang didapat.

Negotiation, ini menetapkan harga produk sesuai dengan kesepakatan kedua belah pihak antara konsumen dengan produsen. Strategi ini sangat baik untuk menjalin hubungan antara perusahaan dengan konsumen agar mereka nyaman dengan harga dan pelayanan yang perusahaan berikan, seperti merespon terhadap kebutuhan pelanggan,memberikan kebebasan pelanggan untuk memilih, dan akhirnya terbentuk kesepakatan yang akan memberikan kenyaman kepada pelanggan sehingga mendorong terbentuknya keunggulan kompetitif yang berkelanjutan di masa yang akan datang.

Pricing strategy sangat mempengaruhi keputusan konsumen untuk membeli produk atau jasa yang mereka butuhkan. Perilaku konsumen sangat menentukan untuk menciptakan keputusan pembelian, sama halnya dengan perilaku pembelian organisasi (tamu bisnis), hanya saja pada pembelian pada sebuah organisasi atau perusahaan banyak sekali pertimbangan-pertimbangan pada saat menentukan sebuah keputusan dan dipengaruhi sejumlah orang yang terlibat di dalam pengambilan keputusan.

Sheryl E. Kimes dalam jurnal Pricing and Revenue Management 2009 yang mengungkapkan "In order to successfully use price as a strategic weapon, firms must address two questions: what prices to charge and how to determine which customers or market segments should be offered those prices determine his decision". Sedangkan Stowe Shoemaker and Anna S. Mattila dalam jurnal Pricing In Services 2009 yang berpendapat "services have characteristics that make pricing in a different service with the goods". 
Menurut Achmad Buchory (2010:76) sejumlah orang yang memiliki keterlibatan dalam proses pengambilan keputusan pembelian pada organisasi diantaranya yaitu, initiator, users, influencers, decider, approvers, buyers, dan gatekeeper, sedangkan menurut Robbins \& Coulter (2010:161) proses pengambilan keputusan yang dilakukan organisasi diantaranya yaitu, identifikasi masalah, identifikasi kriteria keputusan, alokasi bobot kriteria, pengembangan alternatif, analisis alternatif, pemilihan alternatif, implementasi alternatif, dan evaluasi efektifitas keputusan bersama dalam organisasi.

Ada beberapa faktor yang menjadi kriteria sebuah keputusan, menurut Achmad Buchory (2010:75), ada lima keputusan yang dilakukan oleh pembeli organisasi, yaitu:

1. Spesifikasi Produk

Deciders akan menilai dan melihat produk mana yang akan memenuhi kriteria users, setelah itu approvers akan memutuskan pembelian yang akan dilakukan oleh buyers. Dalam hal iniperusahaan harus mengetahui produk yang bagaimana yang dapat memenuhi kebutuhan sebuah organisasi yang menjadi pangsa pasarnya. Misalnya bentuk layout kapasitas meeting room dan sebagainya yang dibutuhkan sebuah perusahaan yang akan mengadakan meeting.

2. Waktu Pembelian

Keputusan organisasi dalam memilih waktu pembelian bisa berbeda-beda yang disesuaikan dengan kegiatan organisasi tersebut, oleh sebab itu perlu adanya kontak antara penyedia dengan organisasi, misalnya jam pembelian, dan kapan mereka akan mengadakan meeting.

3. Jumlah Pemesanan

Organisasi dapat mengambil keputusan seberapa banyak jumlah yang akan dipesan oleh organisasi pada setiap pembeliannya. Misalnya jumlah peserta yang akan meeting dan berapa jumlah meeting room yang akan digunakan.

4. Syarat Pembayaran

Setiap organisasi memilih sebuah produk yang akan digunakan oleh anggotanya, organisasi tersebut pasti akan melakukan sebuah transaksi. Pada saat transaksi inilah biasanya organisasiada yang melakukan pembayaran secara tunai maupun mebebankan pada organisasinya. Hal ini tergantung dari kesanggupan buyers dalam melakukan suatu transaksi.

5. Pilihan Saluran Distribusi

Organisasi harus mengambil keputusan mana yang akan digunakan untuk melakukan booking-an meeting room yang akan digunakan. Setiap organisasi berbeda-beda dalam hal menentukan cara yang mana yang paling efektif dikarenakan faktor lokasi, harga, dan persediaan meeting room yang tersedia dan sebagainnya.

Pricing strategy demand based methods yang membentuk keputusan pembelian pada sebuah organisasi, memegang peranan penting bagi kemajuan setiap perusahaan produk dan jasa. Faktorfaktor penentu yang digunakan dalam proses keputusan pembelian terhadap pricing strategydemand based methods yang dijalankan perusahaan terdiri dari buyer based pricing, psychological pricing, dan negotiation dengan mengukur melalui faktor keputusan pembelian sebuah organisasi yang terdiri dari spesifikasi produk, waktu pembelian, jumlah pemesanan, syarat pembayaran, dan pilihan saluran distribusi.

Berdasarkan penjelasan teori di atas, secara teoritis penjelasan pricing strategy demand based methods yang terdiri dari buyer based pricing, psychological pricing dan negotiation mempunyai hubungan yang positif terhadap keputusan pembelian. Keterkaitan antara dua konsep di atas merupakan kerangka berpikir yang dijadikan landasan dalam penelitian sebagaimana terlihat dalam bagan kerangka pemikiran seperti yang disajikan Gambar 2.3 berikut ini:

Berdasarkan kerangka pemikiran maka disusun paradigma penelitian penciptaan keputusan penggunaan meeting package pada tamu wisatawan bisnis melaluidemand based pricing methods yang terdiri daribuyer based pricing, psychological pricing, dan negotiation. Sedangkan keputusan penggunaan meeting packageadalah, spesifikasi produk, waktu pembelian, jumlah pemesanan, syarat pembayaran, pilihan saluran distribusi. Secara jelas digambarkan dalam Gambar 4 di bawah ini: 


\section{Demand Based Pricing Methods}

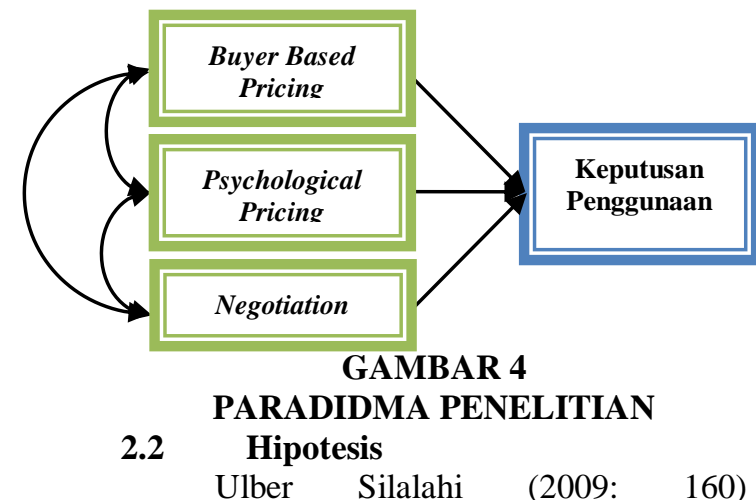

mengutarakan bahwa Hipotesis merupakan pernyataan atau jawaban tentatif atas masalah dan kemudian hipotesis dapat diversifikasi hanya setelah hipotesis diuji secara empiris. Jadi, hipotesis juga dapat dinyatakan sebagai jawaban teoritis terhadap rumusan masalah penelitian, belum merupakan jawaban yang empirik.

Berdasarkan penyusunan hipotesis penelitian ini, didukung oleh beberapa premis yang mendukung bahwa pricing strategy mempunyai pengaruh terhadap keputusan penggunaan (pembelian) sebagai berikut:

1. Menurut Compeau dalam Solomon (2011:95) mengatakan survey consistentlyshow that consumers consider price the most important factor when they buy.

2. Ali Hasan (2009:298) mengutarakan bahwa harga mempengaruhi kinerja finansial dan memiliki pengaruh penting terhadap persepsi pembelian.

3. Fandy Tjiptono (2009:468) mengungkapkan bahwa berdasarkan hukum permintaan harga mempengaruhi pembelian, semakin tinggi harga semakin sedikit permintaan, sebaliknya semakin rendah harga semakin tinggi permintaan.

4. Harga merupakan faktor utama penentu posisi dan harus diputuskan sesuai dengan pasar sasaran, bauran ragam produk, dan pelayanan, serta persaingan. (Kotler dan Amstrong dalam Bernard 2009:78)

5. Gregorius Chandra (2008:468) berpendapat bahwa Harga bersifat fleksibel, artinya dapat disesuaikan dengan cepat. Dari empat unsur bauran pemasaran tradisional, harga adalah elemen yang paling mudah diubah dan diadaptasikan dengan dinamika pasar. Berdasarkan hukum permintaan, besar kecilnya harga mempengaruhi kuantitas produk yang dibeli konsumen.

6. Eric T. Anderson and Duncan I. Simester dalam jurnal Price cues and customer price knowledge (2009:150) yang mengungkapkan"Pricing strategy is one of the marketing tactics used to convince customers that the prices provide good value compared with competitors' prices and will affect customers to evaluate a price that in its decision

Berdasarkan uraian permasalahanpermasalahan di atas, maka penulis merumuskan bahwa:

"Terdapat pengaruh secara positif antara keputusan penggunaan meeting packagedi Hotel Bumi Asih Jaya Bandung melalui demand based pricing methods yang terdiri daribuyer based pricing, psychological pricing, dan negotiation"

\section{METODE PENELITIAN}

\subsection{Objek Penelitian}

Pendekatan ilmu yang digunakan dalam penelitian ini adalah ilmu manajemen pemasaran. khususnya manajemen pemasaran jasa yang berkaitan dengan industri perhotelan yang terdiri dari demand based pricing methods dengan keputusan penggunaan pada tamu bisnis.

Penelitian ini dilakukan untuk menganalisis mengenai penciptaan keputusan penggunaan meeting package di Hotel Bumi Asih Jaya Bandung melalui demand based pricing methods. Adapun yang menjadi objek penelitian sebagai variabel bebas adalah demand based pricing methods (X) yang terdiri daribuyer based pricing (X1), psychological pricing (X2), dan negotiating (X3). Sedangkan untuk variabel terikat (Y) adalah keputusan penggunaan pada tamu bisnis yang terdiri dari spesifikasi produk, waktu penggunaan, jumlah pesanan, syarat pembayaran, dan pilihan saluran distribusi. Responden dalam penelitian ini adalah tamu bisnis Hotel Bumi Asih Jaya Bandung yang terdiri dari corporate dan government.

\subsection{Metode Penelitian}

Metode merupakan cara kerja untuk mencapai suatu tujuan atau pendekatan yang dilakukan untuk mencapai suatu hal. Menurut Sugiyono (2010:2) yang dimaksud dengan metode penelitian adalah "cara ilmiah untuk mendapatkan data dengan tujuan dan kegunaaan tertentu". Data yang diperoleh melalui penelitian itu adalah data empiris yang mempunyai kriteria tertentu yaitu valid. 
Valid menunjukan derajat ketepatan antara data yang sesungguhnya terjadi pada obyek dengan data yang dikumpulkan oleh peneliti.

\subsubsection{Jenis Penelitian dan Metode yang} Digunakan

Penelitian ini digunakan metode deskriptif dan verifikatif menurut Sugiyono (2008:35) menjelaskan bahwa penelitian deskriptif adalah suatu penelitian yang merupakan sebuah uraian sistematis tentang teori dan hasil-hasil penelitian yang relevan dengan variabel yang diteliti sehingga mendapatkan gambaran dari variabel penelitian. Melalui jenis penelitian deskriptif maka dapat diperoleh deskripsi mengenai gambaran demand based pricing methods dan keputusan penggunaan meeting package di Hotel Bumi Asih Jaya Bandung.

Sifat pengujian verifikatif pada dasarnya ingin menguji kebenaran dari suatu hipotesis yang dilaksanakan melalui pengumpulan data di lapangan seperti yang diungkapakan oleh Arikunto (2006:7), bahwa "penelitian verifikatif pada dasarnya bermaksud menguji kebenaran dari suatu hipotesis yang dilaksanakan melalui pengumpulan data di lapangan." Penelitian ini menguji pengaruh demand based pricing methods terhadap keputusan penggunaan meeting package di Hotel Bumi Asih Jaya Bandung.

Berdasarkan jenis penelitian di atas yaitu penelitian deskriptif dan verifikatif yang diaksanakan melalui pengumpulan data dilapangan, maka metode yang digunakan adalah explanatory survey. Menurut Sugiyono (2008:10), metode explanatory survey merupakan metode penelitian yang bermaksud menjelaskan kedudukan variabelvariabel yang diteliti serta pengaruh antara satu variabel dengan variabel yang lain.

Penelitian ini dilakukan pada kurun waktu tertentu, maka metode yang digunakan adalah cross section method (Husein Umar, 2004:43) adalah metode penelitian dengan cara mempelajari objek, dalam kurun waktu tertentu tidak berkesinambungan dalam jangka waktu panjang. Pada penelitian dengan penggunaan metode ini, informasi dari sebagian populasi dikumpulkan langsung ditempat kejadian secara empirik dengan tujuan untuk mengetahui pendapat dari sebagian populasi terhadap objek yang sedang diteliti.

\subsubsection{Operasionalisasi Variabel}

Variabel yang dikaji dalam penelitian ini meliputi demand based pricing methods (X) yang terdiri daribuyer based pricing
(X1), psychological pricing (X2), dan negotiating (X3). Sedangkan keputusan penggunaan pada tamu bisnis sebagai variabel (Y) dengan dimensi spesifikasi produk, waktu penggunaan, jumlah pemesanan, syarat pembayaran dan pemilihan saluran distribusi. 
TABEL 3

OPERASIONALISASI VARIABEL

\begin{tabular}{|c|c|c|c|}
\hline $\begin{array}{c}\text { Variabel/Sub } \\
\text { Variabel } \\
\end{array}$ & Konsep & Indikator & Ukuran \\
\hline 1 & 2 & 3 & 4 \\
\hline $\begin{array}{l}\text { Demand Based } \\
\text { Pricing Methods } \\
\text { (X) }\end{array}$ & $\begin{array}{l}\text { Penetapan harga yang } \\
\text { berfokus pada perspektif } \\
\text { pelanggan dan memberikan } \\
\text { pertimbangan kepada } \\
\text { pelanggan. Hudson } \\
(2008: 191)\end{array}$ & & \\
\hline $\begin{array}{l}\text { Buyer Based } \\
\text { Pricing } \\
\text { (X1) }\end{array}$ & $\begin{array}{l}\text { Penetapan harga sesuai } \\
\text { dengan permintaan dan } \\
\text { penawaran pelanggan. } \\
\text { Hudson }(2008: 192)\end{array}$ & $\begin{array}{l}\text { - } \begin{array}{l}\text { Kemenarikan harga } \\
\text { meeting package yang } \\
\text { ditawarkan. }\end{array} \\
\text { - } \begin{array}{l}\text { Kesesuaian harga meeting } \\
\text { package dengan fasilitas. }\end{array} \\
\text { - Kesesuaian flexibilitas } \\
\text { harga meeting package. }\end{array}$ & $\begin{array}{l}\text { - } \text { Tingkat kemenarikan harga } \\
\text { meeting package yang } \\
\text { ditawarkan dengan permintaan } \\
\text { konsumen. } \\
\text { - Tingkat kesesuaian harga } \\
\text { meeting package dengan } \\
\text { fasilitas yang diinginkan } \\
\text { konsumen. } \\
\text { - Tingkat flexibelitas harga } \\
\text { meeting package. }\end{array}$ \\
\hline $\begin{array}{l}\text { Psychological } \\
\text { Pricing } \\
\text { (X2) }\end{array}$ & $\begin{array}{l}\text { Penetapan harga sesuai } \\
\text { dengan persepsi pelanggan } \\
\text { dalam hubungan harga } \\
\text { dengan nilai produk. Hudson } \\
(2008: 192)\end{array}$ & $\begin{array}{l}\text { - } \begin{array}{l}\text { Kemenarikan harga } \\
\text { discount meeting package. }\end{array} \\
\text { - } \quad \begin{array}{l}\text { Kesesuaian harga meeting } \\
\text { package dengan manfaat. }\end{array} \\
\text { - } \quad \text { Kepercayaan terhadap } \\
\text { kesesuaian harga meeting } \\
\text { package dengan kualitas } \\
\text { pelayanan yang diberikan } \\
\text { oleh hotel. } \\
\text { Keyakinan terhadap } \\
\text { kesesuaian harga yang } \\
\text { dibayarkan dengan variasi } \\
\text { produk meeting package. }\end{array}$ & $\begin{array}{l}\text { - Tingkat kemenarikan harga } \\
\text { discountmeeting package per- } \\
\text { bulannya. } \\
\text { - Tingkat kesesuaian harga } \\
\text { meeting package dengan } \\
\text { manfaat yang diberikan. } \\
\text { - Tingkat kepercayaan terhadap } \\
\text { kesesuaian harga meeting } \\
\text { package dengan kualitas } \\
\text { pelayanan yang diberikan oleh } \\
\text { hotel. } \\
\text { - Tingkat terhadap kesesuaian } \\
\text { harga yang dibayarkan dengan } \\
\text { variasi produk meeting } \\
\text { package. }\end{array}$ \\
\hline $\begin{array}{l}\text { Negotiating } \\
\text { (X3) }\end{array}$ & $\begin{array}{l}\text { Penetapan harga sesuai } \\
\text { dengan keinginan kedua belah } \\
\text { pihak. Hudson (2008:193) }\end{array}$ & $\begin{array}{l}\text { - Kemudahan dalam } \\
\text { bernegoisasi harga } \\
\text { meeting package. } \\
\text { - Kesesuaian harga meeting } \\
\text { package dengan } \\
\text { keinginan tamu. } \\
\text { - Kenyamanan dalam } \\
\text { bernegoisasi. }\end{array}$ & $\begin{array}{l}\text { - Tingkat kemudahan dalam } \\
\text { bernegoisasi harga meeting } \\
\text { package. } \\
\text { - Tingkat kesesuain harga } \\
\text { meeting package dengan } \\
\text { keinginan tamu. } \\
\text { - Tingkat kenyamanan dalam } \\
\text { bernegoisasi }\end{array}$ \\
\hline
\end{tabular}

LANJUTAN TABEL 3

OPERASIONALISASI VARIABEL

\begin{tabular}{|c|c|c|c|}
\hline $\begin{array}{c}\text { Variabel/Sub } \\
\text { Variabel } \\
\end{array}$ & Konsep & Indikator & Ukuran \\
\hline 1 & 2 & 3 & 4 \\
\hline \multirow[t]{4}{*}{$\begin{array}{l}\text { Keputusan } \\
\text { Penggunaan } \\
\text { (Y) }\end{array}$} & \multirow[t]{4}{*}{$\begin{array}{l}\text { Tahap dalam pengambilan } \\
\text { keputusan penggunaan di } \\
\text { mana konsumen benar-benar } \\
\text { membeli produk atau jasa } \\
\text { (Achmad Buchory }(2010: 75) \text {. }\end{array}$} & - Spesifikasi Produk & $\begin{array}{l}\text { - Tingkat keberagaman jenis } \\
\text { meeting room hotel. } \\
\text { - Tingkat keindahan desain interior } \\
\text { dan eksterior meeting room hotel. } \\
\text { - Tingkat kelengkapan fasilitas } \\
\text { meeting package. }\end{array}$ \\
\hline & & - Waktu Penggunaan & $\begin{array}{l}\text { - Tingkat penggunaan pada waktu } \\
\text { dan kondisi tertentu (adanya } \\
\text { program promo). }\end{array}$ \\
\hline & & - Jumlah Penggunaan & $\begin{array}{l}\text { - Tingkat frekuensi penggunaan } \\
\text { meeting package di hotel. }\end{array}$ \\
\hline & & - Metode pembayaran & $\begin{array}{l}\text { - Tingkat kemudahan pembayaran } \\
\text { meeting package secara cash. } \\
\text { - Tingkat kemudahan pembayaran } \\
\text { meeting package dengan } \\
\text { menggunakan kartu kredit, debit } \\
\text { dan sistem pembayaran lainnya } \\
\text { yang ditawarkan. }\end{array}$ \\
\hline
\end{tabular}




\begin{tabular}{|c|c|c|c|}
\hline $\begin{array}{c}\text { Variabel/Sub } \\
\text { Variabel }\end{array}$ & Konsep & Indikator & Ukuran \\
\hline 1 & 2 & 3 & 4 \\
\hline & & $\begin{array}{l}\text { - Pemilihan Saluran } \\
\text { Distribusi }\end{array}$ & $\begin{array}{l}\text { - Tingkat pemilihan karena lokasi } \\
\text { strategis. } \\
\text { - Tingkat kemudahan aksesibilitas } \\
\text { menuju hotel. } \\
\text { - Tingkat kemudahan melakukan } \\
\text { reservasi melalui telepon. } \\
\text { - Tingkat kemudahan melakukan } \\
\text { reservasi melalui online } \\
\text { reservation. } \\
\text { - Tingkat kemudahan melakukan } \\
\text { reservasi secara langsung (walk- } \\
\text { in). }\end{array}$ \\
\hline
\end{tabular}

\subsubsection{Metode Penarikan Sampel}

Sampel dalam penelitian ini yaitu sebagian dari populasi tamu Hotel Bumi Asih Jaya Bandung. Dalam penelitian ini sampel sebanyak 48 tamu hotel dengan penghitungan sensus. Ulber Silalahi (2009: 261) bahwa pemilihan sampel jenuh adalah proses pemilihan sampel bila semua anggota populasi digunakan sebagai sampel. Berdasarkan hal tersebut, yang menjadi sampel dalam penelitian ini adalah tamu bisnis yang menentukan keputusan penggunaan meeting package di Hotel Bumi Asih Jaya Bandung.

\subsubsection{Prosedur Pengumpulan Data}

Pengumpulan data yang dilakukan penulis menggunakan teknik sebagai berikut:

1. Kuesioner/angket

2. Studi Literatur

3. Wawancara

3.3 Hasil Pengujian Validitas dan Reliabilitas

\subsubsection{Hasil Pengujian Validitas}

Berdasarkan hasil pengolahan data dengan menggunakan software komputer SPSS 11,5 menunjukkan bahwa item-item pertanyaan dalam kuesioner valid karena $\mathrm{r}_{\text {hitung }}$ lebih besar jika dibandingkan dengan $\mathrm{r}_{\text {tabel }}$ yang bernilai 0,374 .

\subsubsection{Hasil Pengujuian Reabilitas}

Hasil pengujian reliabilitas demand based pricing methodsyang terdiri dari buyer based pricing, psychological pricing, dan negotiation dengan keputusan penggunaan yang terdiri dari spesifikasi produk, waktu penggunaan, jumlah penggunaan, metode pembayaran, dan pemilihan saluran distribusi. Pengujian tersebut menggunakan SPSS 11,5dengan model product moment (Pearson) dapat dikatakan reliabel. Hal tersebut dikarenakan nilai reliabiliatas untuk kedua variabel tersebut sebesar 0.867 dan 0.866 lebih besar dari nilai minimal yaitu 0.50 .

TABEL 4

PENGUJIAN RELIABILITAS

\begin{tabular}{|c|l|c|c|}
\hline No & \multicolumn{1}{|c|}{ Variabel } & Alpha cronbach & Kesimpulan \\
\hline 1 & Demand based pricing methods & 0.867 & Reliabel \\
\hline 2 & Keputusan penggunaan & 0.866 & Reliabel \\
\hline
\end{tabular}

Sumber: Pengolahan data 2010

\subsection{Pengujian Hipotesis}

Teknik untuk menguji data yang digunakan dalam penelitian kuantitatif ini adalah metode analisis verifikatif. maka dilakukan analisis jalur (path analysis). Dalam Hal ini jalur yang digunakan untuk menentukan besarnya variabel independen $\left(\mathrm{X}_{1}, \mathrm{X}_{2} \mathrm{X}_{3}\right)$ dimana buyer based pricing $\left(\mathrm{X}_{1}\right)$ psychological pricing $\left(\mathrm{X}_{2}\right)$. Dan negotiation $\left(\mathrm{X}_{3}\right)$ terhadap $\mathrm{Y}$ baik secara langsung maupun tidak langsung. Pengujian hipotesis dilakukan dengan menggambar struktur hipotesis.

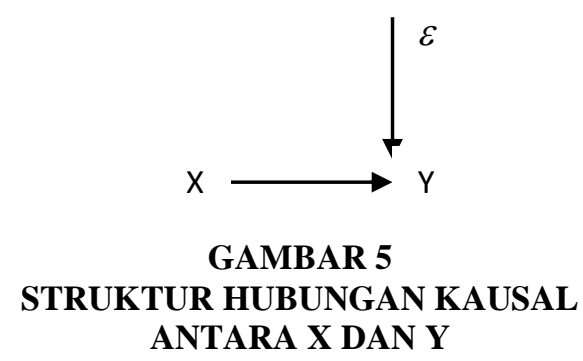


Struktur Hubungan antara $\mathrm{X}$ dan $\mathrm{Y}$ diuji melalui analisis jalur dengan hipotesis terdapat pengaruh yang signifikan antara demand based pricing methods yang terdiri dari buyer based pricing $\left(\mathrm{X}_{1}\right)$ psychological pricing $\left(\mathrm{X}_{2}\right)$. Dan negotiation $\left(\mathrm{X}_{3}\right)$ terhadap keputusan penggunaan meeting package $(\mathrm{Y})$. Selanjutnya struktur hubungan diatas diterjemahkan kedalam hipotesis yang menyatakan pengaruh variabel bebas yang dominan terhadap variabel terikat. Untuk lebih jelas dapat dilihat pada Gambar 6 Berikut:

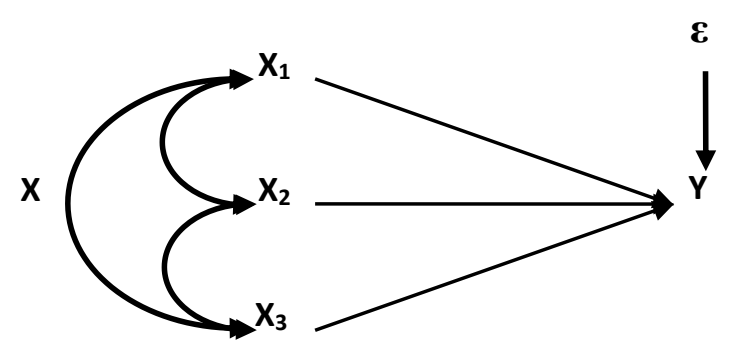

\section{GAMBAR 6 \\ DIAGRAM JALUR SUB STRUKTUR HIPOTESIS UTAMA}

\section{HASIL PENELITIAN} PEMBAHASAN

DAN

4.1 Gambaran Demand Based Pricing Methods di Hotel Bumi Asih Jaya Bandung

Tanggapan tamu Hotel Bumi Asih Jaya Bandung terhadap ketiga dimensi demand based pricing methods dengansub variabel demand based pricing methods yang mendapatkan penilaian tertinggi yaitu buyer based pricing sebesar84\%, hal ini menunjukan bahwa demand based pricing methods berupa buyer based pricing dirasakan oleh tamu sebagai hal yang paling bermanfaat selama tamu tersebut menggunakan fasilitas meeting package di Hotel Bumi Asih Jaya Bandung. Buyer based pricing ini digunakan untuk menetapkan harga agar tepat sesuai dengan harapan tamu seperti yang dikatakan oleh kotler dan keller (2009:419), banyaknya konsumen menggunakan harga sebagai indikator dari kualitas suatu produk atau jasa dan konsumen akan mencari berbagai macam informasi mengenai harga, manfaat, dan kualitas produk yang konsumen inginkan dengan berbagai alternatif.

\subsection{Gambaran Keputusan Penggunaan di \\ Hotel Bumi Asih Jaya Bandung}

Rekapitulasi mengenai hasil penilaian keputusan penggunaan di Hotel Bumi Asih
Jaya Bandung berada pada posisi penilaian yang sangat tinggi. sub variabel keputusan penggunaan meeting package yang mendapatkan nilai teringgi adalah waktu penggunaan sebesar $88 \%$. Hal ini menunjukan bahwa waktu penggunaan yang dirasakakan tamu, menjadi pilihan pertama dalam menentukan keputusan penggunaan, ketersediaan meeting room dan kesiagaan pihak hotel dalam mempersiapkan kebutuhan tamu bisnisnya menjadikan nilai baik dari tamu bisnis yang telah menggunakan fasilitas meeting package di Hotel Bumi Asih Jaya Bandung. Sedangkan sub variabel yang paling rendah adalah pemilihan saluran distribusi sebesar $82.6 \%$. Hal ini dikarenakan terkadang lokasi hotel yang terletak pada bagan jalan yang besar membuat para tamu harus memutar balik arah yang cukup jauh, dan kurangnya fasilitas hiburan di sekitar hotel.

\subsection{Pengaruh Demand Based Pricing} Methods terhadap Keputusan Penggunaan Meeting Package di Hotel Bumi Asih Jaya Bandung

Pengujian hipotesis dilakukan untuk menguji besarnya pengaruh demand based pricing methods $(\mathrm{X})$ yang terdiri dari buyer based pricing $\left(\mathrm{X}_{1.1}\right)$, psychological pricing $\left(\mathrm{X}_{1.2}\right)$, dannegotiation $\left(\mathrm{X}_{1.3}\right)$ terhadap keputusan peenggunaan meeting package $(\mathrm{Y})$ baik secara simultan ataupun parsial, dilakukan dengan menggunakan uji statistik analisis jalur (path analysis). Selain itu, terdapat faktor-faktor lain yang mempengaruhi hubungan antara demand based pricing methods $(\mathrm{X})$ yang terdiri dari buyer based pricing $\left(\mathrm{X}_{1.1}\right)$, psychological pricing $\left(\mathrm{X}_{1.2}\right)$, dannegotiation $\left(\mathrm{X}_{1.3}\right)$ terhadap keputusan peenggunaan meeting package $(\mathrm{Y})$ yaitu variabel residu yang dilambangkan dengan $\varepsilon$, namun pada penelitian ini variabel tersebut tidak diperhitungkan, serta untuk menguji hipotesis dihitung besarnya koefisien jalur masing-masing variabel.

Berdasarkan perhitungan statistik yang didasarkan pada angka-angka dari masing-masing variabel terlebih dahulu dilakukan transformasi, dimana dalam perhitungan transformasi dilakukan dengan program yang ada dalam SPSS Versi 11,5. Secara lengkap hasil pengolahan data pengaruh demand based pricing methods besertatiga sub variabelnya terhadap keputusan penggunaan meeting package disajikan secara rinci dalam Tabel 5 sebagai berikut: 
TABEL 5

MATRIKS KORELASI ANTAR SUB VARIABEL DEMAND BASED PRICING METHODS DAN KEPUTUSAN PENGGUNAAN

\begin{tabular}{|c|c|c|c|c|}
\hline & $\begin{array}{c}\underline{Y} \\
\text { (keputusan } \\
\text { penggunaan) }\end{array}$ & $\begin{array}{c}\underline{\mathrm{X} 1} \\
\begin{array}{c}\text { Buyer Based } \\
\text { Pricing) }\end{array}\end{array}$ & $\begin{array}{c}\underline{\mathrm{X} 2} \\
\begin{array}{c}\text { Psychological } \\
\text { Pricing) }\end{array}\end{array}$ & $\frac{\underline{\mathrm{X} 3}}{(\text { Negotiation) }}$ \\
\hline (keputusan $\frac{\underline{Y}}{\mathbf{p} e n g g u n a a n)}$ & 1 & 0.664 & 0.723 & 0.834 \\
\hline (Buyer Based Pricing) & 0.664 & 1 & 0.388 & 0.590 \\
\hline$\stackrel{\text { X2 }}{\text { (Psychological Pricing) }}$ & 0.723 & 0.388 & 1 & 0.489 \\
\hline$\frac{\mathrm{X3}}{\text { (Negotiation) }}$ & 0.834 & 0.590 & 0.489 & 1 \\
\hline
\end{tabular}

Sumber: Hasil Pengolahan Data 2011

Berdasarkan hasil matriks korelasi antara sub variabel demand based pricing methods terhadap keputusan penggunaan, diperoleh hasil korelasi secara berurutan yaitu, buyer based pricing (0.664), psychological pricing (0.723), dan negotiation (0.834)

Berdasarkan tabel di atas pengaruh langsung antara tiga sub variabel $\mathrm{X}$ dengan variabel Y yang memiliki korelasi terbesar adalah negotiation dengan keputusan penggunaan yaitu sebesar 0,834. Koefisien tersebut menunjukkan bahwa antara negotiation dengan keputusan penggunaan memiliki hubungan yang signifikan, sedangkan korelasi terbesar antara variabel X adalah buyer based pricing dan negotiation yaitu sebesar 0,590. Koefisien tersebut menunjukkan bahwa antara buyer based pricing dengan negotiation memiliki hubungan yang signifikan.

Hasil matriks pada tabel di atas diketahui korelasi terendah antara variabel $\mathrm{X}$ dan variabel $\mathrm{Y}$ adalah buyer based pricing dengan keputusan penggunaan yaitu sebesar 0,664 sedangkan korelasi terendah antara variabel $\mathrm{X}$ adalah buyer based pricing dan psychological pricing sebesar 0,388. Secara lengkap untuk mengetahui pengaruh masingmasing demand based pricing methods terhadap keputusan penggunaan disajikan pada Gambar 7 sebagai berikut:

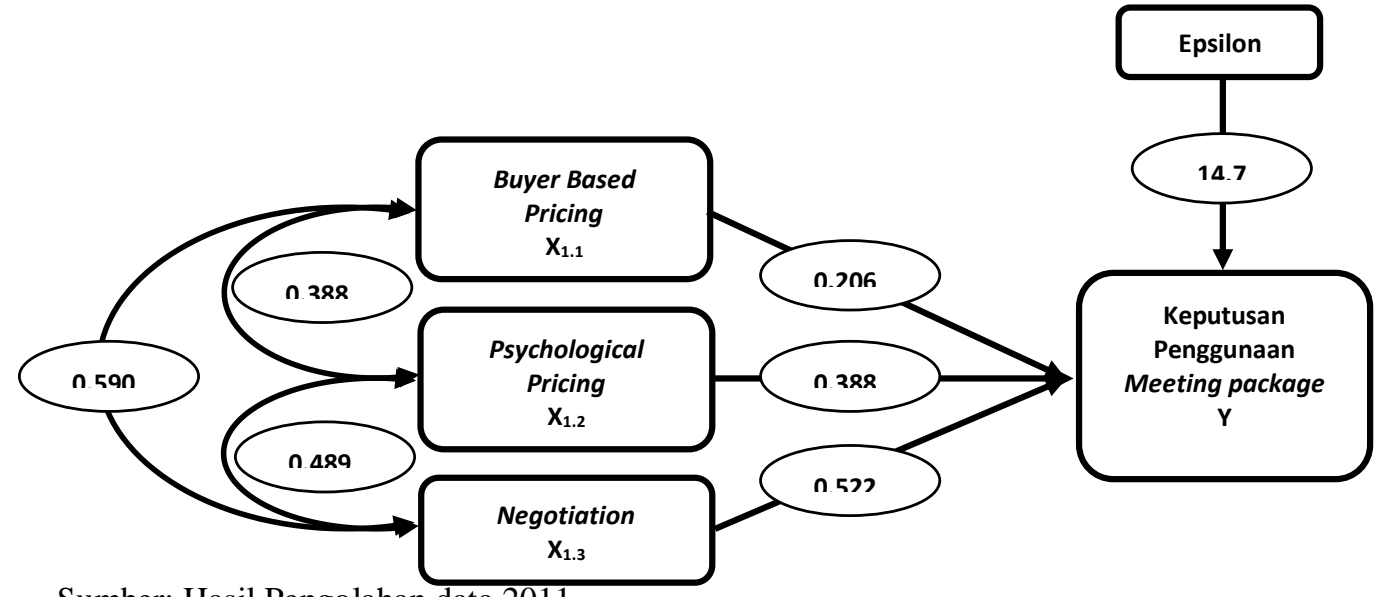

Sumber: Hasil Pengolahan data 2011

GAMBAR 7

DIAGRAM JALUR PENGUJIAN HIPOTESIS

Berdasarkan hasil korelasi selanjutnya akan dilakukan uji $\mathrm{F}$ untuk mengetahui hasil hipotesis. Besarnya nilai korelasi di atas membuktikan dengan penolakan Ho yang dilakukan dengan uji $\mathrm{F}$ tingkat signifikasi (sig) sama dengan 0,000 atau lebih kecil dari 0,05 . 
TABEL 6

HASIL PENGUJIAN KOEFISIEN JALUR, PENGARUH LANGSUNG DAN TIDAK

LANGSUNG DARI DEMAND BASED PRICING METHODS DALAM UPAYA MENINGKATKAN KEPUTUSAN PENGGUNAAN MEETING PACKAGE DI HOTEL BUMI ASIH JAYA BANDUNG

\begin{tabular}{|c|c|c|c|c|c|c|c|c|}
\hline \multirow[t]{2}{*}{$\mathbf{X}$} & \multirow{2}{*}{$\begin{array}{c}\text { Pengaruh } \\
\text { Langsung } \\
\text { Terhadap Y }\end{array}$} & \multicolumn{3}{|c|}{$\begin{array}{c}\text { Pengaruh Tidak Langsung } \\
\text { Melalui }\end{array}$} & \multirow[t]{2}{*}{$\mathbf{R}^{2}{ }_{\mathrm{YX} 1.1, \ldots . . \mathrm{YX} 1.5}$} & \multirow[t]{2}{*}{$\begin{array}{c}t_{\text {hitung }} \\
t_{\text {Tabel }} \mathbf{1 . 6 7 5} \\
\end{array}$} & \multirow[t]{2}{*}{ Sig } & \multirow[t]{2}{*}{ Keputusan } \\
\hline & & $\mathrm{X}_{1.1}$ & $\mathbf{X}_{1.2}$ & $\mathbf{X}_{1.3}$ & & & & \\
\hline $\mathrm{X}_{1.1}$ & 0.042 & - & 0.031 & 0.063 & 0.136 & 2.847 & 0.007 & Ho ditolak \\
\hline $\mathbf{X}_{1.2}$ & 0.150 & 0.031 & - & 0.1 & 0.281 & 5.797 & 0,000 & Ho ditolak \\
\hline $\mathrm{X}_{1.3}$ & 0.272 & 0.063 & 0.1 & - & 0.435 & 6.837 & 0.000 & Ho ditolak \\
\hline $\mathbf{R}^{2}$ & & & & & 0.853 & & & \\
\hline
\end{tabular}

Sumber: Hasil Pengolahan Data 2011

Pengujian hipotesis melalui nilai signifikansi dan uji-t menghasilkan penolakan terhadap Ho, karena nilai signifikasi lebih kecil dibandingkan dengan 0,05 . Hal tersebut berarti bahwa terdapat pengaruh yang signifikan antara demand based pricing methods yang terdiri dari buyer based pricing (X1), psychological pricing (X2), dan negotiation (X3) terhadap keputusan penggunaan $(\mathrm{Y})$.

Demand based pricing methods yang paling tinggi pengaruhnya terhadap keputusan penggunaan adalah negotiation yang berpengaruh secara langsung yaitu sebesar $27.2 \%$, pengaruh tidak langsung melalui buyer based pricing sebesar 6.3\%, dan melalui psychological pricing sebesar $10 \%$. Hal ini dikarenakan tamu yang menggunakan meeting package di Hotel Bumi Asih Jaya Bandung ini merupakan tamu bisnis. Tamu bisnis ini cenderung berkelompok dalam artian mereka datang dengan bergerombol, oleh karena itu tamu bisnis ini memiliki target dan budgetnya masing-masing. Dengan sub variabel negotiation inilah tamu merasakan pelayanan yang baik dengan kerjasama yang baik pula seperti yang dikatakan oleh Zeithaml (2009:524), menentukan harga berdasasarkan perspektif konsumen memberikan nilai terhadap sebuah harga produk baik dari segi kualitas maupun manfaat yang dirasakan konsumen.

\subsubsection{Pengaruh Secara Simultan}

Penolakan terhadap Ho didukung dengan fakta yang ada di lapangan bahwa demand based pricing methods yang dilakukan oleh pihak Hotel Bumi Asih Jaya Bandung merupakan strategi yang ditekankan oleh pihak Hotel Bumi Asih Jaya Bandung guna meningkatkan keputusan penggunaan meeting package di Hotel Bumi Asih Jaya Bandung.

Berdasarkan hasil perhitungan di atas dapat diketahui bahwa pengaruh demand based pricing methodsterhadap Keputusan penggunaan adalah sebesar 0.853 . Sedangkan koefisien jalur variabel lain di luar variabel demand based pricing methods yang terdiri dari buyer based pricing, psychological pricing, dan negotiation ditentukan melalui:

$$
\begin{aligned}
P_{Z \varepsilon} & =\sqrt{1-R_{Y(X 1 \ldots \ldots \ldots X)}^{2}} \\
= & \sqrt{1-0.853} \\
& =0.383
\end{aligned}
$$

Hal tersebut berarti bahwa $X_{1.1}$ sampai $\mathrm{X}_{1.3}$ bersama-sama mempengaruhi keputusan menginap sebesar $85.3 \%$ dan sisanya sebesar $(0.383)^{2} \times 100 \%=14.7 \%$ dipengaruhi faktor lain yang tidak masuk ke dalam penelitian ini.

Berdasarkan hasil analisis tersebut di atas sesuai dengan gambaran umum mengenai demand based pricing methods $(\mathrm{X})$ yang terdiri dari 3 sub variabel yaitu buyer based pricing $\left(\mathrm{X}_{1.1}\right)$, psychological pricing $\left(\mathrm{X}_{1.2}\right)$, dan negotiation $\left(\mathrm{X}_{1.3)}\right)$,terhadap keputusan penggunaan $(\mathrm{Y})$. negotiation-lah yang memiliki pengaruh yang paling besar.

\subsubsection{Pengaruh Secara Parsial}

Demand based pricing methods yang paling tinggi pengaruhnya terhadap keputusan penggunaan adalah negotiation yang berpengaruh secara langsung yaitu sebesar $27.2 \%$, pengaruh tidak langsung melalui buyer based pricing6.3\%, dan melalui psychological pricing sebesar 10\%. Hal ini dikarenakan dengan adanya negotiation memberikan nilai yang lebih pada sebuah produk yang akan dibeli oleh konsumen, dengan menentukan harga dengan kesepakatan bersama antara pihak hotel dengan pihak konsumen, akan memberikan rasa kepercayaan dan rasa keyakinan pula terhadap yang dirasakan oleh konsumen dan akan terjalin hubungan yang baik antara pihak hotel dengan tamunya. 
V. KESIMPULAN

5.1 Kesimpulan

Berdasarkan kajian teori, hasil penelitian, dan pengujian path analysis yang dilaksanakan mengenai demand based pricing methods terhadap keputusan penggunaan meeting package di Hotel Bumi Asih Jaya Bandung, dapat disimpulkan sebagai berikut:

1. Gambaran mengenai demand based pricing methods yang dilaksanakan di Hotel Bumi Asih Jaya Bandung mendapat penilaian yang baik dari tamu Hotel Bumi Asih Jaya Bandung. Penilaian tertinggi diperoleh oleh buyer based pricing, sedangkan penilaian terendah diperoleh oleh negotiation, sepertidijelaskan di bawah ini:

a. Secara keseluruhan demand based pricing methods yang dilaksanakan di Hotel Bumi Asih Jaya Bandung sudah baik, terutama buyer based pricing, dikarenakan buyer based pricing adalah sebuah strategi penetapan harga dimana kemenarikan, kesesuaian, dan keberagamanmenjadi hal yang harus diperhatikan oleh pihak manajemen hotel didalam menawarkan produknya kepada tamu bisnis Hotel Bumi Asih Jaya Bandung. Dengan memiliki konsep harga yang dijelaskan diatas akan menarik para tamu bisnis untuk membeli meeting package yang ditawarkan.

b. Negotiation mendapatkan penilaian terendah.Hal ini dikarenakan dalam bernegoisasi terkadang terdapat ketidaksesuaian antara pihak tamu bisnis dan pihak hotel yang menyebabkan proses tawarmenawar tidak sesuai dengan keinginan dan tidak dapat di follow up lebih lanjut di tambah banyaknya para pesaing yang menawarkan harga yang cenderung sama namun merk hotel pesaing lebih terkenal.

2. Gambaran mengenai keputusan penggunaan meeting package di Hotel Bumi Asih Jaya Bandung secara umum mendapat penilaian yang baik dari tamu bisnis Hotel Bumi Asih Jaya Bandung. Aspek yang memperoleh penilaian tertinggi adalah waktu penggunaan hal ini dikarenakan pihak hotel mampu mengatur proses operasional meeting room yang telah dipesan sesuai dengan permintaan dan jadwal yang telah ditentukan.

3. Demand based pricing methods memberikan pengaruh terhadapkeputusan penggunaan meeting package di Hotel Bumi Asih Jaya Bandung dimana semua sub variabel memberikan pengaruh yang signifikan terhadap keputusan menggunakan meeting package.

\subsection{Rekomendasi}

Demand based pricing methods adalahpenetapan harga yang berfokus pada perspektif konsumen dan memberikan pertimbangan kepada tamu bisnis, dalam hal ini penulis mencoba memberikan saran seperti hal-hal berikut:

1. Secara keseluruhan demand based pricing methods yang dilaksanakan di Hotel Bumi Asih Jaya Bandung sudah dilakukan dengan baik, terdapat tanggapan tamu mengenai demand based pricing methods dimana pada sub variabel negotiation mendapatkan penilaian terendah tetapi dalam penilaian pengaruhan mendapatkan penilaian tertinggi, oleh karena itu pihak hotel harus lebih memperhatikan sub variabel negotiation dalam demand based pricing methods. Rekomendasi yang dapat diberikan kepada Hotel Bumi Asih Jaya Bandung melalui penelitian ini adalah dengan mengadakan pelatihan-pelatihan kepada karyawannya untuk menambahkan skill mereka agar dapat memberikan pelayanan yang optimal dan dapat bernegoisasi dengan baik terhadap para tamu bisnisnya. Rekomendasi pada sub variabel buyer based pricing, yaitu mempertahankan kinerja yang sudah baik dan lebih mengoptimalkan lagi pelayanan dengan memberikan variasivariasi harga dan manfaat yang sesuai dengan kebutuhan para tamu bisnis. Seperti pada saat tamu bisnis yang memesan fullboard meeting package yang merupakan salah satu paket meeting plus menginap, dimana fasilitas yang disediakan ada baiknya ditambahkan dengan complimentary dimasing-masing kamar, salah satunya dengan menyediakan buah-buahan ditambah dengan voucher hotel, dimana dalam beberapa kali pemesan produk meeting di Hotel Bumi Asih Jaya Bandung mendapatkan voucher gratis menginap untuk dua orang. 
2. Keputusan penggunaan meeting package di Hotel Bumi Asih Jaya Bandung juga tinggi. Banyak tamu bisnis yang menggunakan meeting package lebih dari satu kali kedatangan. Hal ini dapat menunjukan bahwa Hotel Bumi Asih Jaya Bandung sudah memiliki tamutamu bisnis yang mempunyai minat tinggi terhadap produk meeting package yang ditawarkan. Namun disamping strategi demand based pricing methods, Hotel Bumi Asih Jaya Bandung harus terus meningkatkan segala aspek yang berhubungan dengan pelayanan, agar keputusan penggunaan meeting package tamu dapat terus meningkat.

3. Strategi yang di jalankan oleh Hotel Bumi Asih Jaya Bandung melalui demand based pricing methods adalah baik, namun pihak manajemen Hotel Bumi Asih Jaya Bandung dapat melakukannya lebih baik lagi, salah satunya dengan dengan memberikan pilihan harga meeting package agar keputusan penggunaan meeting package di Hotel Bumi Asih Jaya Bandung terus meningkat, yang nantinya akan mendapatkan keuntungan bagi kedua belah pihak.

4. Keterbatasan dalam penelitian ini adalah salah satunya objek yang diteliti hanya satu hotel, rekomendasi untuk penelaah selanjutnya adalah untuk tetap meneliti tentang harga, dan dibandingkan antara satu hotel dengan hotel bintang tiga lainnya,karena masing-masing hotel memiliki keunggulannya masing-masing yang disesuaikan melalui harga yang ditawarkan dengan fasilitas yang diberikan.

\section{DAFTAR PUSTAKA}

Ali Hasan (2009). Marketing. Medpress. Buku kita: Jakarta

Bernard T. Widjaja (2009), Lifestyle Marketing: Paradigma Baru Pemasaran Bisnis Jasa. Gramedia Pustaka Utama: Jakarta.

Herry Achmad Buchory. (2009). Manajemen Pemasaran Linda Karya. Bandung.

Eric T. Anderson and Duncan I. Simester. Price Cues And Customer Price Knowledge 2009. MPG Books. Cambridge,USA.

Fandy Tjiptono. (2008). Pemasaran Strategik. Andi. Yogyakarta
(2009).

Service

Marketing.(Esensi \& Aplikasi). Marknensis. Yogyakarta.

Gamal Suwantoro. (2004). Dasar-Dasar Pariwisata, Andi. Yogyakarta.

Lloyo Hudman \& Richard Jackson. 2003. Geograpy Of Travel \& Tourism Fourt Edition Delman Cengage Learning. Clifton Park Usa.

Husein Umar.(2004). Metode Riset Perilaku Organisasi. Jakarta: PT. Gramedia Pustaka Utama

Kotler dan Keller (2009): Manajemen Pemasaran edisi $13^{\text {th }}$. Prentice Hall, New Jersey.

Kotler, Philip. 2006. Manajemen Pemasaran Jilid Satu Edisi Kesebelas, Jakarta: PT. Indeks Kelompok Gramedia.

Lovelock, Wirtz (2011). Service Marketing (people, technology, strategy). Perason Hall

M. Morrison, Alstair. 2002. Hospitality And Travel Marketing Third Edition, United States: Delmar Thompson Learning.

Muljadi A.J. Kepariwisataan Dan Perjalanan. 2009, PT. Rajagrafindo Persada. Jakarta.

Sidmon Hudson, (2008). Tourism and Hospitality Marketing: a Global Perspective. Sage. Los Angeles.

Sugiyono. (2010). Metode Penelitian Bisnis. Bandung: Alfabeta

Suharsimi Arikunto. (2006). Prosedur Penelitian,Suatu Pendekatan Praktek, Jakarta: Rineka Cipta

Ulber Silalahi. (2009) . Metode Penelitian Sosial. Refika Aditama. Bandung

Umar, Husein. (2007) Metode Riset Perilaku Organisasi. Jakarta: PT. Gramedia Pustaka Utama.

Zeithaml, V.A., M.J. Bitner (2009), Service Marketing: Integrating Customer Focus Across the Firm, $5^{\text {th }}$ ed., McGraw-Hill. Boston

Sheryl E. Kimes.Pricing and Revenue Management 2009. MPG Books. Cambridge,USA.

Stowe Shoemaker and Anna S. Mattila. Pricing In Services 2009. MPG Books. Cambridge,USA.

Roger Tony. ConferenceAnd Conventions A Global Industri 2003. ButterworthHeinemann, oxford.

Powers Tom and W Barrows Clayton. 2006. Management in the hospitality industry, John Wiley \& Sons, Inc., Hoboken, New Jersey. 


\section{Website}

www.bandung.go.id (diakses pada tanggal 12 Desember 2010)

www.bandungtourism.com (diakses pada tanggal 6 Januari 2011)

www.bps.go.id/tourism (diakses pada tanggal 6 Januari 2011)

www.digilib/petra.ac.id (diakses pada tanggal 11 Desember 2010)

www.budpar.net (diakses pada tanggal 11

Desember 2010)

www.kompasinteraktif.com (diakses pada tanggal 7 Januari 2011) www.kompas.com (diakses pada tanggal 7 Januari 2011)

www.majalahtrust.com (diakses pada tanggal 15 Desember 2010)

www.swa.co.id (diakses pada tanggal 15 Desember 2010)

www.UNWTO.com (diakses pada tanggal 6 Januari 2011)

www.west-java-indonesia.com (diakses pada tanggal 7 Januari 2011)

www.wikipedia.com (diakses pada tanggal 15 Desember 2010)

Koraninternet.com (diakses pada tanggal 13 Desember 2010). 
